\title{
White Teeth and Healthy Skeletons for All: The Path to Universal Fluoride-Free Drinking Water in Tanzania
}

\author{
Arnaud Igor Ndé-Tchoupé ${ }^{1, *}$, Raoul Tepong-Tsindé ${ }^{1,2}$, Mesia Lufingo $^{3}{ }^{\circledR}$, Zuleikha Pembe-Ali $^{3}$, \\ Innocent Lugodisha ${ }^{3}$, Risala Iddi Mureth ${ }^{3}$, Mihayo Nkinda ${ }^{3}$, Janeth Marwa ${ }^{4}$, \\ Willis Gwenzi ${ }^{5, *} \mathbb{B}$, Tulinave Burton Mwamila ${ }^{6}$, Mohammad Azizur Rahman ${ }^{7}$, \\ Chicgoua Noubactep ${ }^{2} \mathbb{D}$ and Karoli N. Njau ${ }^{3}$ \\ 1 Department of Chemistry, Faculty of Sciences, University of Douala, Douala B.P. 24157, Cameroon; \\ raoultepong@googlemail.com \\ 2 Department of Applied Geology, Universität Göttingen, Goldschmidtstraße 3, D-37077 Göttingen, Germany; \\ cnoubac@gwdg.de \\ 3 Department of Water and Environmental Science and Engineering, Nelson Mandela African Institution of \\ Science and Technology, Arusha P.O. Box 447, Tanzania; lufingom@nm-aist.ac.tz (M.L.); \\ aliz@nm-aist.ac.tz (Z.P.-A.); lugodishai@nm-aist.ac.tz (I.L.); murethr@nm-aist.ac.tz (R.I.M.); \\ nkindam@nm-aist.ac.tz (M.N.); karoli.njau@nm-aist.ac.tz (K.N.N.) \\ 4 Department of Humanities, Governance and Leadership, Nelson Mandela African Institution of Science and \\ Technology, Arusha P.O. Box 447, Tanzania; janeth.marwa@nm-aist.ac.tz \\ 5 Biosystems and Environmental Engineering Research Group, Department of Soil Science and Agricultural \\ Engineering, Faculty of Agriculture, University of Zimbabwe, Mount Pleasant, Harare \\ P.O. Box MP167, Zimbabwe \\ 6 Department of Water Resources and Irrigation Engineering, Water Institute, Dar es Salaam 11000, Tanzania; \\ tulinave.mwamila@waterinstitute.ac.tz or mtulinave@gmail.com \\ 7 Leibniz Institute for Applied Geophysics (LIAG), Geocenter Hannover, Stilleweg 2, 30665 Hannover, \\ Germany; MohammadAzizur.Rahman@leibniz-liag.de \\ * Correspondence: ndetchoupe@gmail.com (A.I.N.-T.); wgwenzi@yahoo.co.uk or \\ wgwenzi@agric.uz.ac.zw (W.G.); Tel.: +263-024-303211 (ext. 15548) (A.I.N.-T.)
}

Received: 14 December 2018; Accepted: 9 January 2019; Published: 12 January 2019

\begin{abstract}
Fluorosis has been prevalent in the great East African Rift Valley (EARV) since before this region was given a name. In the Tanganyika days, Germans reported elevated fluoride concentrations in natural waters. In the 1930s, the clear relationship between high fluoride level and mottling of teeth was established. Since then, the global research community has engaged in the battle to provide fluoride-free drinking water, and the battle is not yet won for low-income communities. An applicable concept for fluoride-free drinking water in the EARV was recently presented, using the Kilimanjaro as a rainwater harvesting park. The Kilimanjaro concept implies that rainwater is harvested, stored on the Kilimanjaro mountains, gravity-transported to the point of use, eventually blended with natural water and treated for distribution. This article provides a roadmap for the implementation of the Kilimanjaro concept in Tanzania. Specifically, the current paper addresses the following: (i) presents updated nationwide information on fluoride contaminated areas, (ii) discusses the quality and quantity of rainwater, and current rainwater harvesting practices in Tanzania, (iii) highlights how low-cost water filters based on $\mathrm{Fe}^{0} /$ biochar can be integrating into rainwater harvesting (RWH) systems to provide clean drinking water, and (iv) discusses the need for strict regulation of RWH practices to optimize water collection and storage, while simplifying the water treatment chain, and recommends strict analytical monitoring of water quality and public education to sustain public health in the EARV. In summary, it is demonstrated that, by combining rainwater harvesting and low-cots water treatment methods, the Kilimanjaro concept has the potential to provide clean drinking water, and overcome fluorosis on a long-term basis. However, a detailed design process is required
\end{abstract}


to determine: (i) institutional roles, and community contributions and participation, (ii) optimal location and sizing of conveyance and storage facilities to avoid excessive pumping costs, and (iii) project funding mechanisms, including prospects for government subsidy. By drawing attention to the Kilimanjaro concept, the article calls for African engineers and scientists to take the lead in translating this concept into reality for the benefit of public health, while simultaneously increasing their self-confidence to address other developmental challenges pervasive in Africa.

Keywords: bone char technique; defluoridation technologies; rainwater harvesting; slow sand filter; water treatment; zerovalent iron

\section{Introduction}

Provision of safe drinking water and the effective removal and subsequent disposal of human and domestic wastes (sanitation) are vital for human health as underlined by Goal 6 of the UN Sustainable Development Goals [1]. Access to safe drinking water is a fundamental human right [2], but universally providing such a service is still challenging for many low-income countries [3-6]. In certain regions, the situation is exacerbated by the occurrence of naturally occurring contaminants of which arsenic $[4,7]$, fluoride $[8,9]$ and uranium $[10,11]$ are the most widespread $[12,13]$. Given that fluoride is often stable in water, and has a very small ionic size, it is very difficult to remove from the aqueous phase [8,14-17]. High fluoride concentration $(>1.5 \mathrm{mg} / \mathrm{L})$ in drinking water causes dental and skeletal fluorosis. Therefore, the provision of fluoride-free drinking water provides a long-term solution to overcoming fluorosis.

During the past eight decades, enormous technical efforts to supply low-income communities with fluoride-free water have shown very limited success [8,15-24]. This sad situation has motivated the search for non-technical solutions, and culminated in the presentation of a concept based on rainwater harvesting (RWH) to supply the whole East African Rift Valley (EARV) with fluoride-free drinking water conforming to the World Health Organization standard of $\left[\mathrm{F}^{-}\right]<1.5 \mathrm{mg} \mathrm{L}^{-1}$ [25]. The named concept utilizes the Kilimanjaro Mountain as a large park for RWH tanks from which stored fluoride-free water is gravity-transported to the community in need. Water from the storage tanks can be blended with natural water to eliminate the need of technical defluoridation, and the remaining contaminants can be removed by filtration using systems containing activated carbon, biochar, metallic iron $\left(\mathrm{Fe}^{0}\right)$, and other efficient materials to achieve acceptable regulatory levels.

The present study focuses on addressing the problem of fluoride contamination of drinking water sources, which has been intensively characterized for the past six decades [24,25]. The Kilimanjaro concept for the provision of fluoride-free water is a combination of at least four mutually independent technological branches: (i) RWH [26-29], (ii) low-cost water treatment [30-33], (iii) water transportation [30,33], and (iv) system modeling [34-38]. In this case, system modeling is considered as stand-alone branch, although it supports the three other branches [39,40]. The design and installation techniques of all aspects of RWH are adapted from conventional civil engineering applications. As far as water treatment is concerned, system modeling is dependent on the used treatment material (e.g., biochar, $\mathrm{Fe}^{0}$ ) evolved from water treatment principles.

The purpose of this communication is to pave the way for the integration of the three first named individually mature technologies necessary for the implementation of the Kilimanjaro concept using Tanzania as a case study. The specific objectives are to: (i) highlight the severity and distribution of fluoride contaminated water in Tanzania, (ii) discuss the quality and quantity of rainwater, and current rainwater harvesting practices in Tanzania, (iii) discuss how the integration of rainwater harvesting systems within the Kilimanjaro catchment and low-cost water treatment methods can provide clean drinking water and overcome fluorosis (the Kilimanjaro concept), and (iv) discuss the institutional and regulatory framework necessary for the implementation of the concept. 


\section{Fluoride Contamination in Tanzania}

With more than 55.6 million people, Tanzania is the fourth most populous country in sub-Saharan Africa [41]. Among the six East African Community members, Tanzania is the largest in geographic size $\left(365,756 \mathrm{~km}^{2}\right)$ and the second largest in economic size, behind Kenya [41]. Only $60 \%$ of Tanzanians are reported to have access to an improved drinking water source [41]. There are concerns about the concept of 'improved drinking water source' [42]. With the advances in analytical instruments, and the availability of regulations, each water source should be analytically characterized to determine the nature and extent of contamination. In the East African Rift Valley, including Tanzania, high fluoride in drinking water originates from geogenic sources [43-45]. In fact, a country map for fluoride contamination in Tanzania has been developed (Figure 1). Figure 1 clearly shows that Mara and Rukwa regions of Tanzania have fluoride concentrations lower than $0.13 \mathrm{mg} / \mathrm{L}$. Both regions are geographically isolated from each other, with Mara being closer to the Kilimanjaro Mountains than Rukwa. Data reported by Malago et al. [45] showed that the Arusha region had the highest aqueous fluoride concentration with an average value of $13.57 \pm 64.16 \mathrm{mg} / \mathrm{L}$. This is followed by Manyara, which has the second highest fluoride concentration $(7.98 \pm 5.73 \mathrm{mg} / \mathrm{L})$, and then the Kilimanjaro region $(7.44 \pm 13.26 \mathrm{mg} / \mathrm{L})$. The Dar es Salaam region was reported to have the lowest aqueous fluoride concentrations $(0.12 \pm 0.11 \mathrm{mg} / \mathrm{L})$, which is below the WHO maximum guideline limit of $1.5 \mathrm{mg} / \mathrm{L}$.

Altogether, Figure 1 and the data from Malago et al. [45] showed that there are fluoride-free, low-fluoride and high-fluoride regions in Tanzania. The Kilimanjaro concept proposes harvesting rainwater and collecting fluoride-free and fluoride poor water and transports it to storage stations on the Kilimanjaro Mountains (Figure 2). The African population, who are already used to a network of pipelines for oil and gas transport for export, will equally learn to accept pipelines for safe drinking water for neighboring regions. For example, Rukwa and Mara regions can be considered as already self-reliant in fluoride-free drinking water, and could export both harvested rainwater and collected fluoride-free spring waters to other regions. 


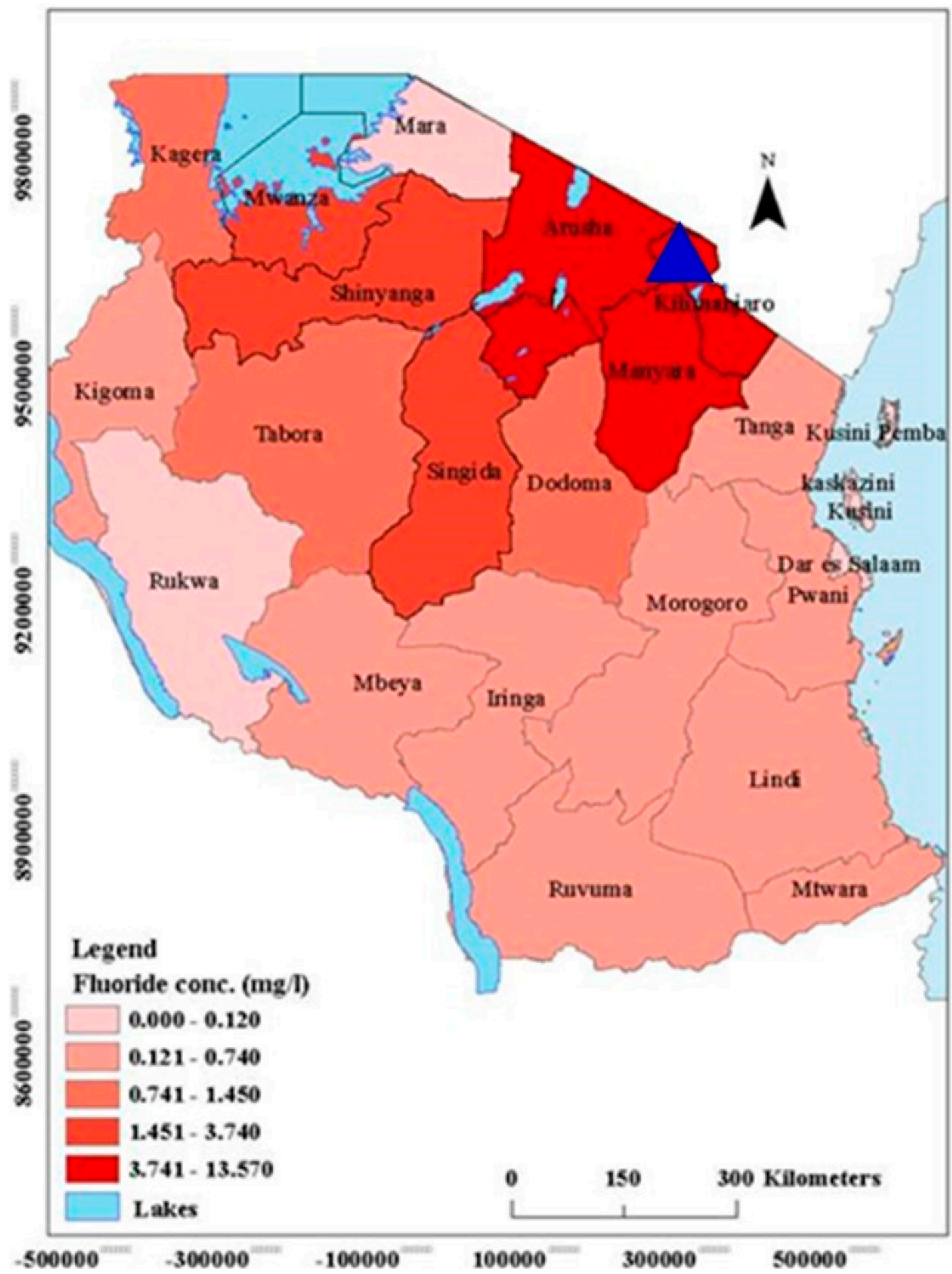

Figure 1. A map of Tanzania showing fluoride distribution by regions (from ref. [45]). The blue triangle $(\boldsymbol{\Delta})$ indicates the location of Kilimanjaro Mountains. 


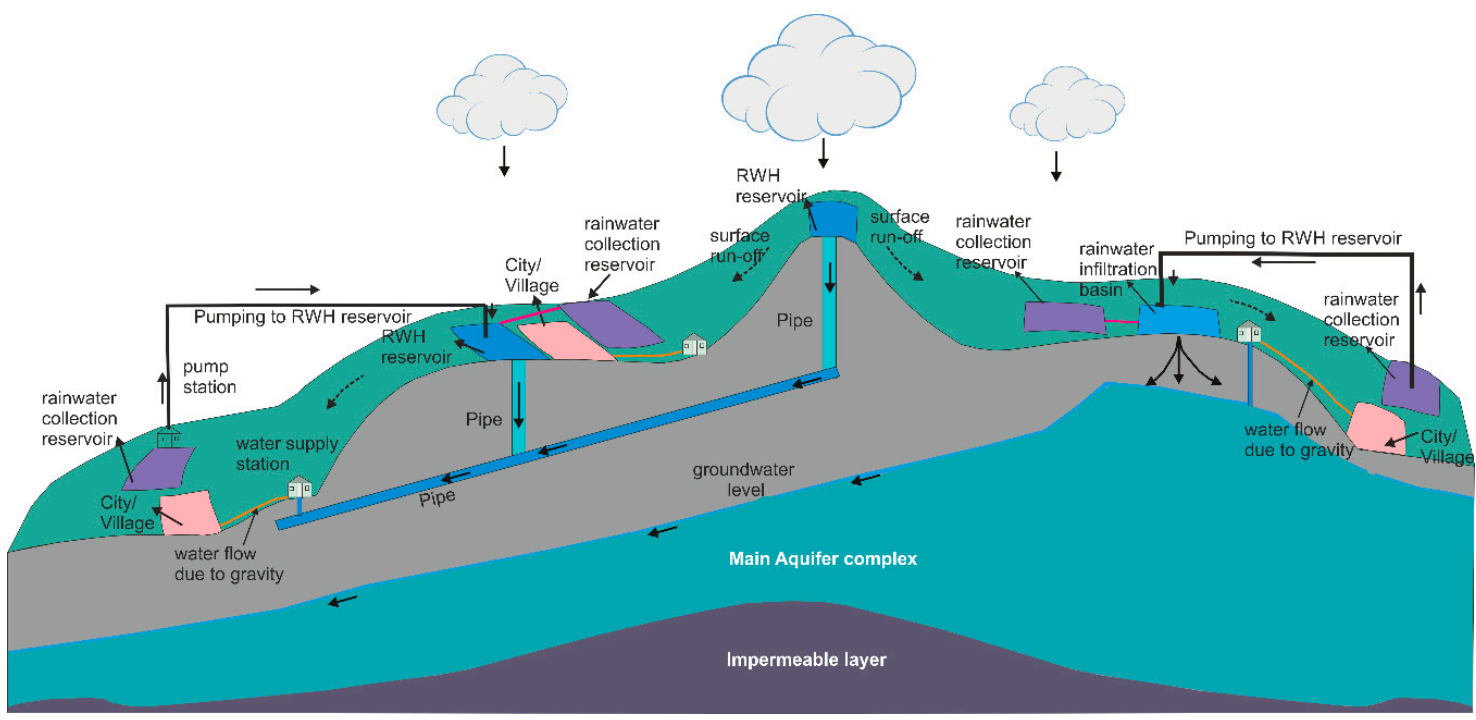

Figure 2. Schematic illustration of the Kilimanjaro concept: rainwater is harvested, locally stored in villages and cities, and then pumped for storage in stations on mountains. Water from the storage stations is then gravity-fed to water treatment plants. The water is conveyed through a pipe network to avoid contact with fluoride-rich geological materials. The diagram is not drawn to scale.

\section{The Kilimanjaro Concept}

\subsection{Overview of RWH in Tanzania}

RWH has a long history in Tanzania, and indigenous knowledge exists on the utilizing rainwater especially for agricultural purposes. Traditional rainwater harvesting structures, include storage structures (known locally as ndiva) in Kilimanjaro Region, excavated bunded basins (majaluba) in the lake zone, and raised broad basins (vinyungu) in Iringa Region. These systems have been sustainable for centuries due to their compatibility with local lifestyles, and institutional and social systems [46]. For domestic purposes, it is common to find people aligning their water collecting devices such as buckets, pots, jars, basins, and drums under roof eaves during the rainy season. However, due to limited storage capacity, water from such RWH systems hardly lasts to the dry season. A number of studies have been conducted to promote the sustainability of RWH systems in Tanzania [47-51]. Therefore, the Kilimanjaro concept builds on this existing local knowledge, and extends it to an even larger scale by incorporating conveyance and storage facilities, and low-cost water treatment systems.

\subsection{General Aspects}

The Kilimanjaro concept entails four sequential steps (Figure 2): (i) roof rainwater is collected (not only in fluoride-contaminated regions), (ii) collected water is locally stored and pumped to storage stations in the Kilimanjaro Mountains, (iii) stored water is gravity-transported to the community in need, and (iv) water is treated and distributed to the population [25]. The concept is analogous to a wastewater treatment system in a modern city, where wastewater is collected from various water users, and delivered to a plant for treatment $[33,52]$. The treatment plants clean wastewater to a required standard for discharge into streams or other receiving waters, or for reuse.

The basic precaution to conserve the quality of harvested rainwater for a longer time is to avoid contact with the ground and ambient environment (atmosphere) and thus prevent breeding of insects including malaria-causing mosquitoes $[25,53]$. There are two basic stages in the treatment of harvested rainwater; primary and secondary. In the primary stage, solids are removed by physical sieving using grid or fine sand filtration. The primary treatment occurs ideally during the collection stage. As rainwater enters a local storage tank, it flows through a screen, which removes large floating objects such as leaves and sticks. After the water has been screened, it passes into a grit column, where sand 
and other suspended solids settle to the bottom. After the screening is completed, rainwater ideally contains only dissolved (organic and inorganic) matter. The secondary stage, as proposed herein, uses proven affordable water treatment processes (e.g., $\mathrm{Fe}^{0}$ and biochar filters) to render stored rainwater potable before it is distributed to the population (Section 5).

\subsection{Design Aspects}

The basic rule for sizing a RWH system is that the maximum volume of rainwater should be captured because the demand is not (only) local. This approach implies that systems to collect local excess rainwater beyond the local drinking water requirements are part of the design. Moreover, the water demand of the EARV is expected to be equal to or exceeding the volume of rainwater harvested in the whole region. Therefore, to minimize the reliance on rainwater and the account for the corresponding monthly and seasonal variability, spring water from fluoride-free regions (Section 2) should be systematically taken into account in the detailed design process.

In the current study, the basic concept presented by Marwa et al. [25] is extended as the catchment area remains the whole EARV, but the water sources are explicitly extended to springs with fluoride-free water. This extension accounts for the expected variability associated with yearly periods without rain (dry season). In other words, the water demand of the EARV determines the storage capacity. Clearly, increasing local catchment surface area and locally capturing more rainwater are not the sole tools to meet water demand. The storage capacity in the Kilimanjaro Mountains should be able to receive water from local storage stations. Adequate solar pumping systems are to be designed so that sufficient water is available to supply the whole EARV. To ensure that the system is capable of supplying clean drinking water at all times, including the dry period, there is a need to conduct a detailed reliability analysis. Reliability analysis uses water balance simulations relating water storage to demand and provides an estimate of the risk of failure of the systems [54]. Several techniques have been developed and applied for conducting reliability analysis in RWH [54,55].

The population of the EARV should soon be used to water pipelines transporting harvested RW and/or fluoride-free spring water to huge storage stations in the Kilimanjaro. In this effort, giant pipelines are expected from highly productive springs to the Kilimanjaro. The catchment areas of such springs are to be transformed into water protection areas, with no land use practices likely to contaminate water sources (e.g., agriculture, mining). These environmental requirements imply that the successful implementation and operation of the Kilimanjaro concept requires a strong political and stakeholder willingness to ensure long-term sustainability.

\subsection{Environmental Aspects}

The Kilimanjaro concept regionally harvests rainwater and stores it in reservoirs on the mountain. Introducing harvesting, pumping, storing and transporting structures is certainly a modification of the natural landscape. These predominantly infrastructural interventions or civil works are unavoidable and represent the price to pay for fluoride-free drinking water. The price is worth paying considering that attaining clean drinking water via defluoridation is challenging, and the proposed concept will provide a long-term solution to the problem of fluorosis. A fundamental environmental question is whether the hydrology of the mountain will change significantly due to RWH and the associated civil structures along the slope. Although this question is difficult to answer, it is obvious that water is not artificially added to the natural landscape in the hilly regions. The existing studies report that RHW is an effective tool to reduce peak flows caused by rainfall in the collecting areas, and thus avoiding erosion and floods and their associated human and environmental impacts [53-57]. In this regard, the hydrological impacts of RWH according to the Kilimanjaro concept are positive, but further detailed studies involving hydrological modeling are required to better understand these potential impacts.

Another important question is the impact on groundwater recharge. This question is more difficult to answer and represents an important research topic in the framework of implementing the Kilimanjaro concept. For example, a review investigating hydrological impacts of RWH in urban 
settings in water limited environments concluded that the impacts on groundwater are difficult to predict, and will depend on how the harvested water is used and disposed of [57]. In the same study, the authors reported that the complex network of utility trenches, tunnels, and other buried structures associated with infrastructural or civil works increase the permeability by orders of magnitude. In turn, this creates a hydrogeological system analogous to shallow karst systems, which provide preferential pathways for groundwater recharge. Although subject to further investigations, it can be anticipated that the impact of the proposed concept on groundwater is rather positive because rapid runoff is avoided during the rains and water is slowly infiltrated after use some weeks later.

\section{Rainwater Harvesting in Tanzania: Potential and Perceptions}

Promotion for utilization of RWH technologies is among the goals of the current water policy for rural water supply development in Tanzania [58]. RWH locally plays a role in offsetting water shortages as acknowledged in the national water sector strategy [59]. This supports rural development policy, which states that the central government will create an environment conducive for private sector participation in the development of RWH technology appropriate for rural areas. The right for citizens to establish personal RWH systems within their premises for domestic purposes is given in the act [60]. In the Tanzanian mainland, $61.9 \%$ of households have modern roofs (iron sheets, tiles, concrete) as was revealed by human settlement survey [61]. In view of the other reliable water supply sources, practical factors necessitating the need for increased adoption of RWH technology were highlighted [47-51], suggesting RWH complements conventional water sources resulting in a dual water supply system. Such a dual system increases water self-sufficiency and reduces over-reliance on centralized systems, which are often not accessible to low-income communities.

\subsection{Perceptions of People on RWH Technology}

In April 2017, an online questionnaire was developed and disseminated to district/municipal water engineers (DWEs/MWEs) of all 185 local government authorities (LGAs). This was for the purposes of gathering information on the status of the RWH technology adoption within LGAs. The data collected were compiled and analyzed using IBM SPSS statistics 23 , and the key findings are briefly explained in the subsequent sections.

\subsubsection{Rainwater Quantity}

With regard to the capacity of RWH technology to sufficiently meet daily water demand, about $53 \%$ had ranked it as moderate, while 39\% said it was low. However, rainfall quantity and distribution, catchment size and storage capacity are major contributing factors in ensuring that the water demand is met. For those days when there is no rainwater in storage tanks, $48 \%$ said that they compensate it with groundwater, followed by water from unprotected water sources (31\%), while the remaining $22 \%$ was shared among collecting water from surface sources, public piped sources and others. The Kilimanjaro concept implies that local tanks can store excess water, which can be redistributed when there is shortage. Upon depletion of the local reserve, water from the mountain or from a clean source in the neighboring regions can be supplied to meet water demand.

\subsubsection{Rainwater Quality}

Considering the perception of people on rainwater quality as drinking water, about $33 \%$ rated it as excellent, followed by $30 \%$ for good, $24 \%$ for fair, and the remaining $13 \%$ was distributed between poor and very poor quality. Approximately $45 \%$ of the respondents cited no major complaints on rainwater quality in terms of sediments, insects, odor, color, and taste. No water treatment components are usually included in RWH as suggested by $42 \%$, followed by those using a coarse screen $(27 \%)$ and the remaining $31 \%$ included options such as first flush tanks, sedimentation tanks, and disinfection systems. Approximately 50\% selected boiling as a preferred post-treatment method for rainwater prior consumption, followed by no treatment (30\%) compared to other options, including SODIS, filtration 
(bio-sand/cloth/ceramic) and chlorination. About $88 \%$ indicated that no rainwater quality monitoring was done, while for the few (12\%) who did, physical and microbiological tests were the preferred tests, with each scoring $35 \%$. The remaining 30\% were distributed among other options, including chemical, and a combination of physical, chemical, and microbiological tests. In the context of the Kilimanjaro concept, monitoring water quality will be standardized, and the use of chemicals in water treatment will be avoided.

\subsubsection{RWH System Construction, Maintenance, and Promotion}

RWH system construction and operation and maintenance cost were said to be moderate by $58 \%$ and $62 \%$ respectively. Plastic tanks were highly recommended by $52 \%$ compared to other materials, including ferro-cement, concrete, mortar jars, and dams. Regarding the promotion of RWH technology, $58 \%$ agreed that government has played a greater role in its promotion, followed by the private sector $(31 \%)$. The villagers themselves and the combined efforts of two or more sectors accounted for the remaining $11 \%$. Demonstration pilot projects was the main approach for promoting awareness cited by $53 \%$, followed by presentations in village meetings (44\%), and media and brochure dissemination, which scored $1 \%$ each. About $2 \%$ indicated no need of awareness campaigns because people were already aware of the RWH technology. In summary, there is positive overall perception on RWH technology among Tanzanians, which provides an ideal setting for implementation of the proposed concept.

\subsection{Potential of RWH in Tanzania: the Case of NM-AIST}

The high potential for RWH to serve as a water supply source in Tanzania has been well-demonstrated in earlier studies, including those based on modeling and GIS [47,49,62]. As a case study, the Nelson Mandela Institution for Science and Technology (NM-AIST) located within EARV is also a victim of fluoride contaminated groundwater (Figure 1). For example, fluoride concentrations of 2.9 and $2.7 \mathrm{mg} / \mathrm{L}$ in groundwater from the two most reliable drinking water boreholes were measured by the Arusha Regional Water Laboratory in 2010 [47]. The NM-AIST comprises buildings with roofs made of tiles and galvanized iron, which are ideal for RWH for domestic purposes [63-66]. NM-AIST has a target maximum population of about 1000 people, and the total roof catchment area of existing buildings is approximately $18,300.3 \mathrm{~m}^{2}$. An additional underground $\mathrm{RWH}$ system exists, with a capacity of $800 \mathrm{~m}^{3}$, which is constructed within the laboratory complex. Currently, the system is harvesting rainwater from only $62 \%$ of the complex's roof $\left(2887.4 \mathrm{~m}^{2}\right)$, but is not fully operational and efficient due to leakages.

The analysis of the RWH potential for NM-AIST was performed using a simple daily water balance model with an overall cumulative water storage (Equation (1)). The analysis incorporated the performance parameters for dry season quantification; number of days without water (NWD), and rainwater usage ratio (RUR) (Equations (2) and (3)) [48]. The same authors considered all 365 days of the year, a runoff coefficient of $80 \%$, and utilized daily rainfall data in the analysis (Figure 3). A population of 1000 people was used to estimate daily water consumption in both cases. Fixed demand conditions were considered, keeping in mind the recommended service level [59] of providing a minimum of $70 \mathrm{~L} /$ person/d for consumers with household connections, and a minimum of $25 \mathrm{~L} /$ person/d for consumers with yard connections, and through water points. The difference in water requirements is attributed to the fact that water consumption is more difficult to control for consumers with household connections, while delays caused by queuing for water in public water points tend to reduce consumption. Moreover, consumers with household connections are likely to have higher incomes than those without.

$$
V_{t}=V_{t-1}+Q_{t}-Y_{t}-O_{t}
$$




$$
\begin{gathered}
\text { NWD }=\frac{T-\sum_{t=1}^{T} W D}{T} \times 100 \\
\text { RUR }=\frac{\sum_{t=1}^{T} Y_{t}}{\sum_{t=1}^{T} Q_{t}} \times 100
\end{gathered}
$$

where, $Q_{t}$ is the RW harvested on the $t_{\text {th }}$ day; $V_{t-1}$ is the volume of RW stored in the tank at the beginning of the $t_{\text {th }}$ day; $Y_{t}$ is the RW supplied during the $t_{\text {th }}$ day; WD is a day on which the demand is fully met; $T$ is the total number of days in the year or years considered; $V_{t}$ is the cumulative volume of water stored in the RW tank after the end of the $t_{\text {th }}$ day; and $O_{t}$ is the overflow volume on the $t_{\text {th }}$ day. All volumes are measured in liters.

From the analysis, at a daily demand of $70 \mathrm{~L} /$ person/d with storage of 400,000 L, it shows that $45 \%$ of institute's demand will be met through RWH (Figure 4), while the remainder $55 \%$ will require alternative supplementary water sources. RUR of $87 \%$ will be achieved and 99 days of full demand supply. Figure 5 shows that at a daily demand of $25 \mathrm{~L} /$ person/d with storage of $400,000 \mathrm{~L}, 75 \%$ of institute's demand will be met through RWH, hence alternative water sources will need to meet the remaining demand of $25 \%$. A corresponding RUR of $52 \%$ will be achieved, and 258 days of full demand supply. Comparison of Figures 4 and 5 shows that increasing the storage capacity, and reducing the per capita daily water requirement, increases the capacity of RWH to meet drinking water requirements without groundwater supplementation. Using a per capita water requirement of $10 \mathrm{~L} /$ person/day, scope exists to meet most cooking and drinking water requirement from RWH (Figure 6), while other domestic uses (e.g., toilet flushing) can be met from groundwater supply (i.e., a dual system).

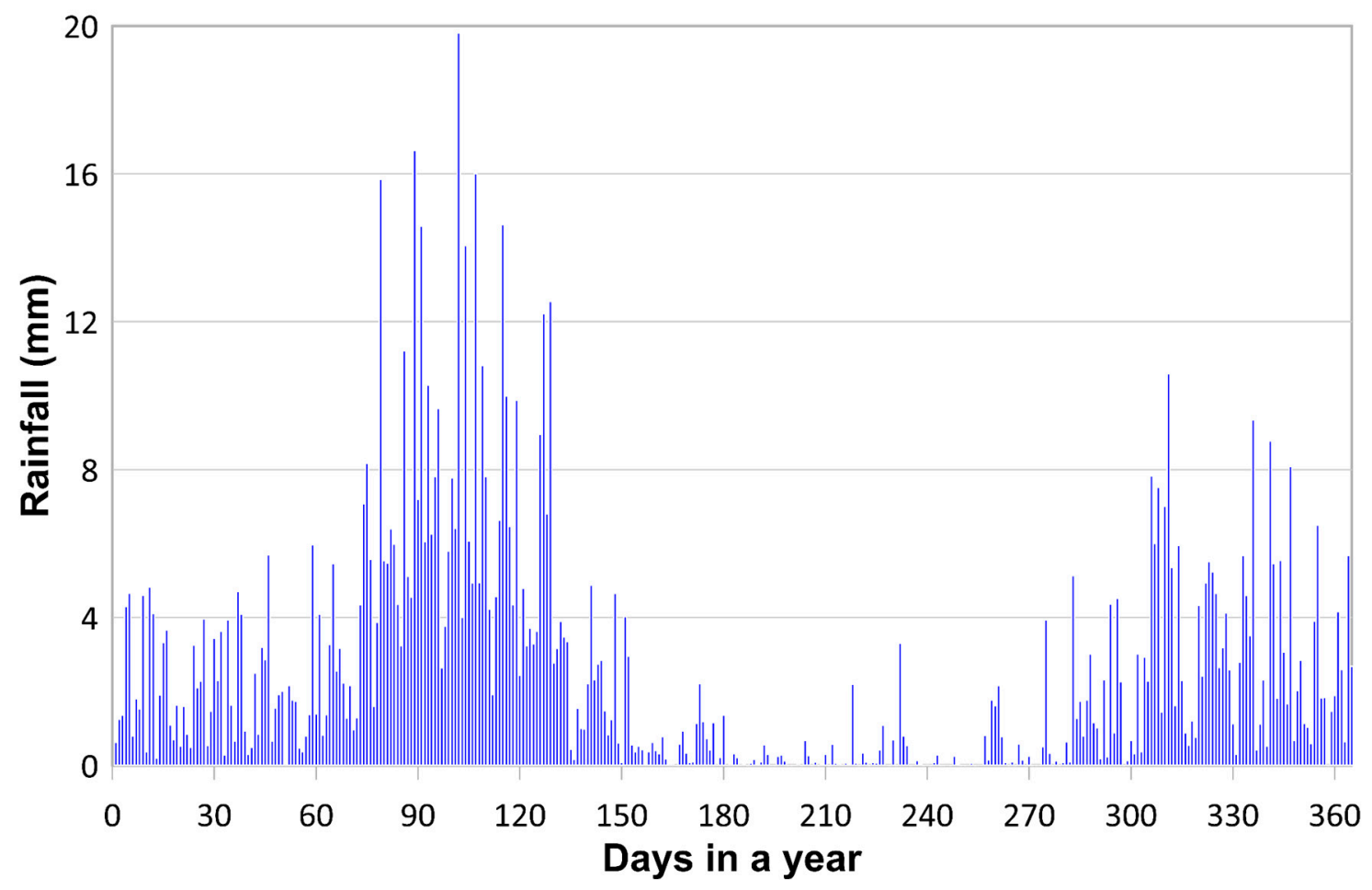

Figure 3. Average daily rainfall data for Arusha for 2000-2014 (Source: Pangani Basin Water Office). 


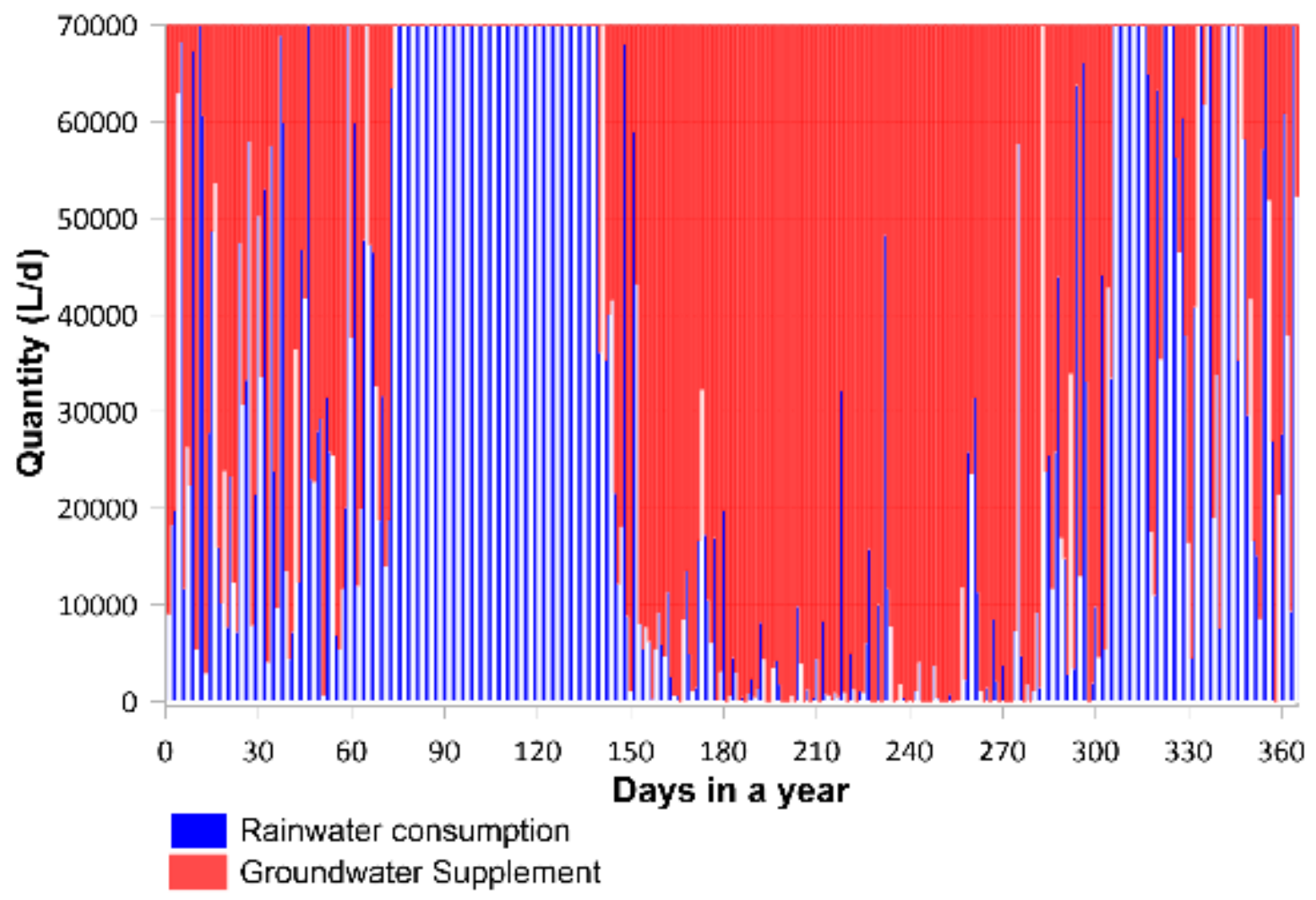

Figure 4. Daily rainwater consumption and required supplement to meet at demand of $70 \mathrm{~L} /$ person/d at NM-AIST with a target maximum population of 1000 people.

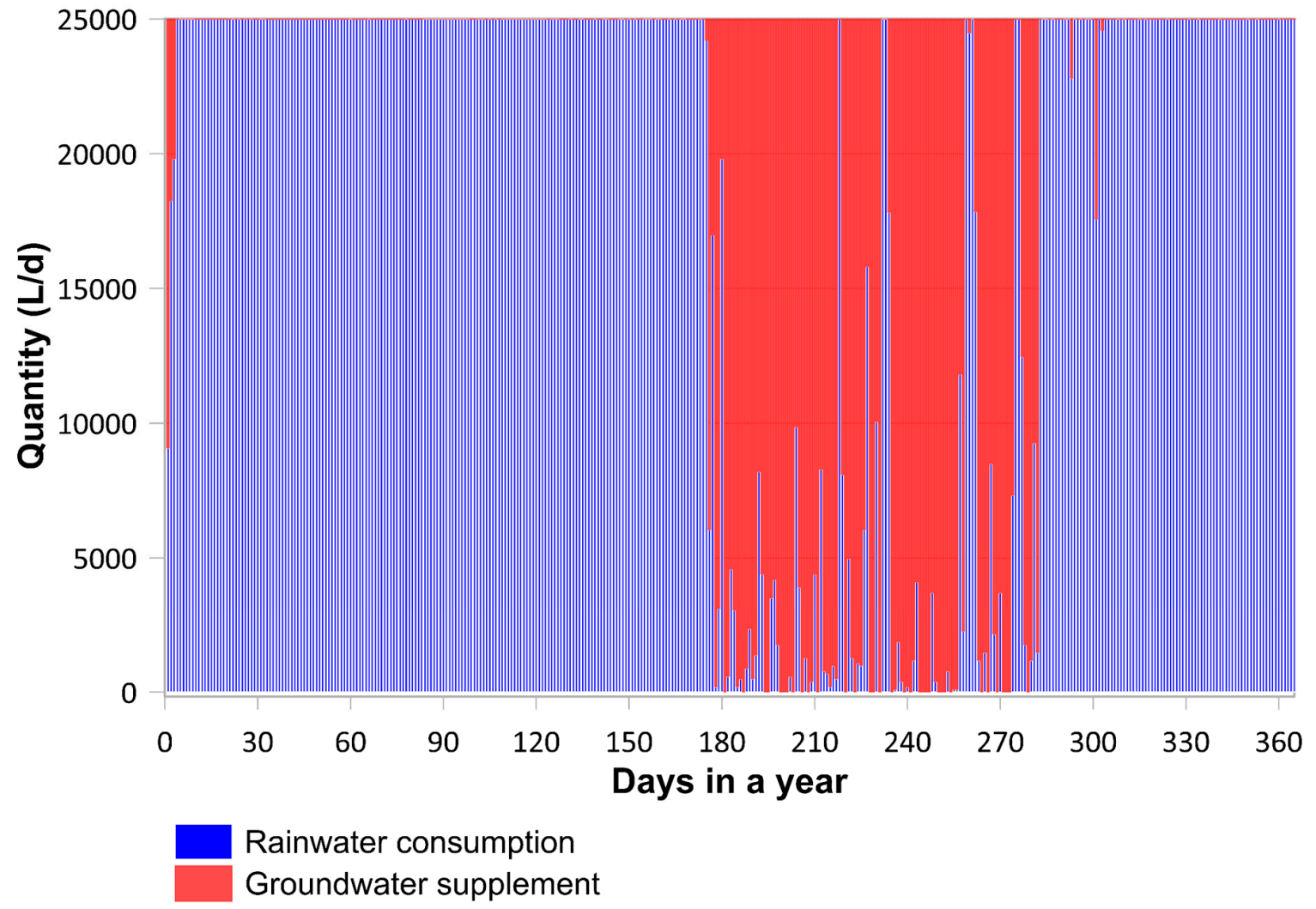

Figure 5. Daily rainwater consumption and required supplement to meet at demand of $25 \mathrm{~L} /$ person/d at NM-AIST with a target maximum population of 1000 people. 


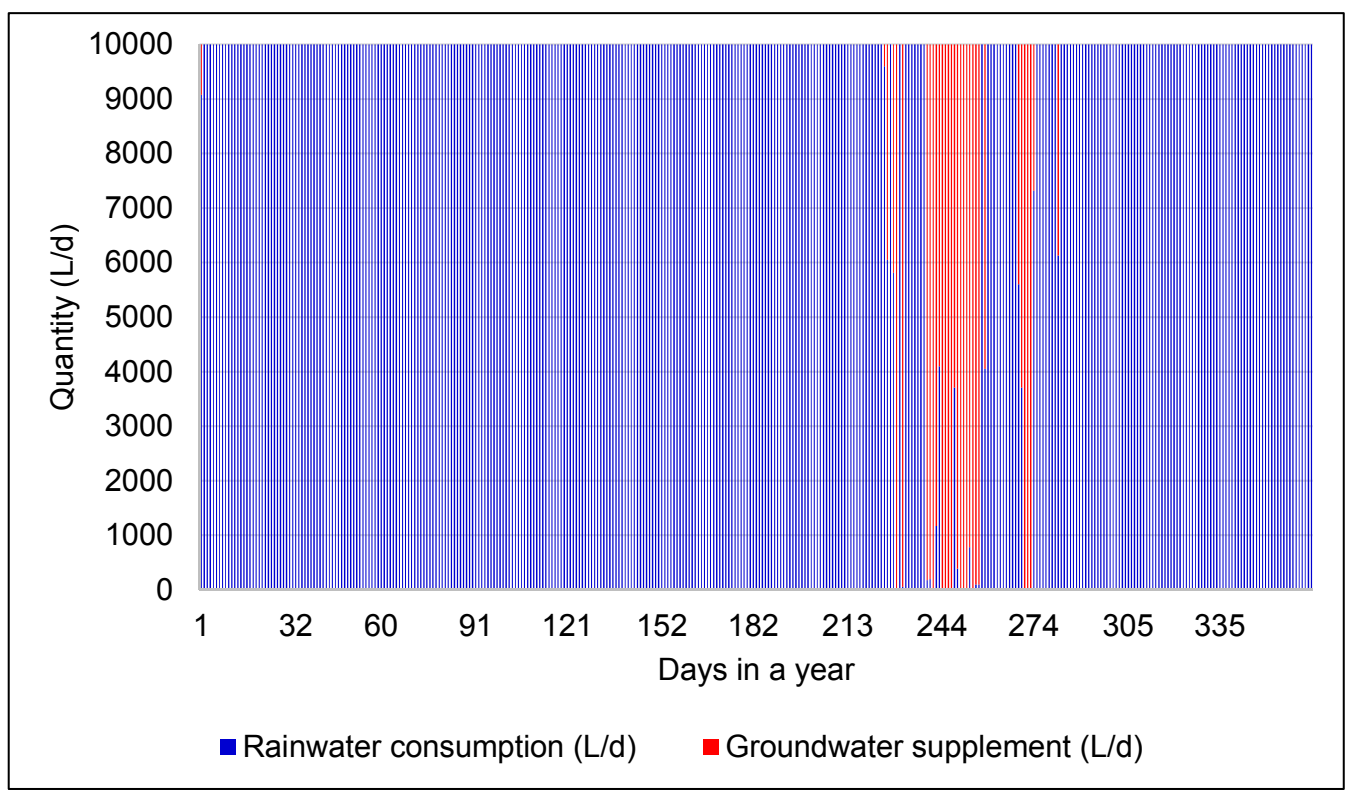

Figure 6. Daily rainwater consumption and required supplement to meet at demand of $10 \mathrm{~L} /$ person/d at NM-AIST with a target maximum population of 1000 people.

The analysis further revealed overflow losses at $13 \%$ and $45 \%$ of harvested water at consumption of 70 and $25 \mathrm{~L} / \mathrm{d}$, respectively. Henceforth, it is necessary to make the most of harvestable rainwater within the EARV, which apart from addressing water supply challenges, also reduced floods due to reduced peak runoff. Under the Kilimanjaro concept, excess rainwater beyond the local water demand and available storage capacity will be transported to storage tanks located in the mountains and used to meet the daily demand of other communities within and beyond EARV. Moreover, there is potential to achieve larger storage reserves by harvesting surface runoff from available paved/cemented areas within household compounds, although this may require further treatment.

\section{Water Treatment}

\subsection{Physico-Chemical and Microbial Quality of Rainwater}

The use of rainwater for drinking purposes is premised on the fact that it is generally considered cleaner than surface water from rivers and dams $[67,68]$. This is because surface runoff mobilizes and accumulates potentially toxic contaminants along its flow path. Moreover, in fluoride prone areas such as AERV, rainwater is expected to have lower concentrations of toxic geogenic contaminants such as $\mathrm{F}$, $\mathrm{U}, \mathrm{As}$, and heavy metals than groundwater. However, a number of studies have shown that rainwater may contain potentially toxic physicochemical and microbial contaminants [69-74].

The bulk of contaminants reported in rainwater are often acquired from atmospheric deposition, roof materials, and conveyance and storage facilities [69-74]. A study by Gwenzi et al. [75] presents a detailed discussion of the occurrence of various contaminants in roof rainwater, and the key factors influencing its quality, including nature and age of roof materials, weather conditions and land use practices. In summary, contaminants commonly reported in roof rainwater include heavy metals such as $\mathrm{Pb}$ and $\mathrm{Al}$ leached from roof materials such as metal sheets, and nitrates from the animal/bird droppings and decomposition of plant material trapped on roofs $[76,77]$. Some studies drawn from Australia $[69,78-80]$ and a few others from South Africa [71,72] have reported pathogenic organisms in roof rainwater. For example, analysis of water samples from 29 rainwater tanks in South Africa showed the presence of both indigenous and pathogenic organisms, including those from eight genera (Klebsiella, Enterobacter, Legionella, Salmonella, Shigella, Yersinia, and Giardia) [71]. In this case, microbial contamination was attributed to animal/bird droppings, gardens and dust and lack of first flush diversion devices [71,72]. Similarly, studies investigating the microbiological quality of rainwater 
in Australia reported the presence of pathogenic organisms, including Salmonella spp, Giardia spp, Aeromonas spp., Campylobacter spp, Cryptosporidium spp, and virulent genes in E. coli and Enterococcus spp. [69,78-80]. These findings suggest that contamination of rainwater may occur on a case-by-case basis. In cases where such contaminations exceed the guideline limits for drinking water, low-cost treatment methods are required to safeguard human health.

\subsection{Appropriate Low-Cost Water Treatment Methods}

Appropriate low-cost water treatment methods for low-income communities should conform to the five criteria [81,82]: (i) they rely on local and readily available materials and technical skills, (ii) have low initial and maintenance costs given the low-income of most households, and in some cases suit small and sparsely distributed households, (iii) be able to function without electricity which is often unavailable, (iv) have capacity to simultaneously remove multiple physicochemical and microbial contaminants, and (v) have no known adverse effects on the treated water. Based on these criteria, several existing low-cost methods can be discounted: (i) chlorination, which often relies on imported chlorine, and generates potentially carcinogenic by-products, and (ii) boiling, which is often recommended for removal of microbial contaminants, increases concentrations of dissolved chemical contaminants. Similarly, membrane technology and nanotechnology rely on imported devices and skills to effectively operate and maintain such systems-both of which are often lacking at the community level.

Two technologies currently meet the highlighted criteria: (i) biochar-based water filters, and (ii) metallic iron $\left(\mathrm{Fe}^{0}\right)$ water filters. Biochar and $\mathrm{Fe}^{0}$ water filters have shown the excellent capacity to remove several contaminants in aqueous systems, including; pathogenic organisms (e.g., bacteria, viruses), dissolved toxic inorganic (e.g., arsenic, nitrate, fluoride, uranium), and organics (e.g., pesticides, pharmaceutical drug residues). Interestingly, resident African scientists in Tanzania, Cameroon, and Zimbabwe have established collaborations with their counterparts abroad (China, Germany, Iran) to provide leadership and advance the two technologies. For example, in a recent review article, a roadmap for the development and application of biochar-based water filters in Africa was highlighted [6]. Similarly, several studies focusing on refining and applying $\mathrm{Fe}^{0}$ filters for water treatment in Africa and elsewhere have been conducted [83-87]. For brevity, a short summary of the fundamental principles and merits of the two technologies is presented here.

\subsubsection{Biochar-Based Water Filters}

Biochar is a carbon-rich low-cost biomaterial developed from the pyrolysis of biomass feedstock. Biochar can be produced from local and readily available cheap biomass materials such as crop residues, weeds, prunings, litter, and even firewood. The various biochar feedstocks available were discussed in an earlier review article focusing on biochar production and applications in Africa [88]. Moreover, several low-cost pyrolysis systems such a flame curtain pyrolyzer (Kon tiki), biochar/gasifier stoves such as the Anila, Elsa, and top-lit updraft (TLUD) stoves and drum kilns can be fabricated from local materials such as scrap metals using local skills [89].

Biochar has several unique physicochemical properties that make them excellent filter media for the removal of contaminants in aqueous systems. Specifically, biochar often has a highly porous microstructure, high specific surface area (SSA), high stability, high cation exchange capacity and a high amount of fixed carbon compared to the pristine biomass. Moreover, several methods exist for the development of engineered biochars with specific physico-chemical properties. For example, metal/metal oxide-biochar composites which behave as hybrid or dual adsorbents have been developed. In such hybrid adsorbents, adsorption occurs on both the biochar matrix and the metal/metal oxide nanoparticles on the biochar surfaces. An increasing body of literature demonstrates that pristine biochar and their activated derivatives have an excellent capacity to various groups of contaminants in aqueous systems, including the three natural inorganic killers (arsenic, fluoride, and uranium) [6]. Moreover, the mechanisms of contaminant removal by biochar are 
relatively well-understood. The capacity of biochars to remove microbiological and physico-chemical contaminants, and the removal mechanisms involved have been the subject of recent reviews [6,90].

A number of conceptual designs of biochar-based water systems have been proposed, depending on the water quality treatment objectives [6]. These include: (i) a biochar layer incorporated as an additional component of a dual/multilayered/sandwich fixed-bed adsorption reactors incorporating conventional sand filter(s) to improve contaminant removal efficiency, (ii) a stand-alone biochar filter that principally uses biochar as a filter media without sand filter(s), either as a single fixed-bed column reactor or a series of such reactors, and (iii) a system consisting of a biochar filter as a single/series of biochar-based fixed-bed adsorption columns, then followed by a polishing phase using physical or chemical disinfection. Moreover, scope exists to design water filters consisting of a sequential configuration of a biochar-sand dual filter first and then followed by a metallic iron filter ( $\mathrm{Fe}^{0}$ filter) that serves to polish the water. The novelty of such a filter system is that it simultaneously takes advantage of the contaminant removal capacities of sand, biochar and $\mathrm{Fe}^{0}$ systems. Such water filter systems are expected to have higher contaminant removal efficiency than those based on a single media.

\subsubsection{Metallic Iron Water Filters}

Using metallic iron $\left(\mathrm{Fe}^{0}\right)$ in water treatment has a century-old scientific history. The technology was established at large scale in Antwerp (Belgium) in 1883 and has been implemented worldwide for several decades $[83,86,90,91]$. The use of $\mathrm{Fe}^{0}$ for clean water provision was abandoned after World War I, but has been independently 'rediscovered' in some critical situations [81,91-97]. For example, James et al. [93] successfully added steel wool to peat and sand to increase phosphate adsorptive removal in wetlands. In another study, Khan et al. [95] used $\mathrm{Fe}^{0}$ to increase the concentration of dissolved iron and enable arsenic co-precipitation.

Studies have shown that $\mathrm{Fe}^{0}$ - and $\mathrm{Fe}^{0}$ /biosand-filters effectively remove pathogenic and indicator organisms in aqueous systems [98-102]. Key mechanisms accounting for the removal of microbiological organisms include inactivation and irreversible adsorption on iron [98,103]. Moreover, several recent studies show that $\mathrm{Fe}^{0} / \mathrm{H}_{2} \mathrm{O}$ can remove toxic metals (e.g., $\mathrm{Zn}, \mathrm{Pb}$ ), metalloids (As, Mo) and radionuclides (e.g., $\mathrm{U}$ ) in aqueous systems [104-112].

The establishment of $\mathrm{Fe}^{0}$ as a universal filter material for water treatment was based on the huge number of treatability studies, demonstrating the efficiency of $\mathrm{Fe}^{0}$ to remove all classes of contaminants, including heavy metals and pathogens $[5,113]$. $\mathrm{Fe}^{0}$ generates colloidal species or corrosion products in situ, which precipitate and act as contaminant scavengers. Because these precipitates are larger in volume than their parent $\left(\mathrm{Fe}^{0}\right)$, clogging is an inherent issue of $\mathrm{Fe}^{0}$ filters and should be addressed in the design step $[114,115]$. There is thus no doubt, that well-designed $\mathrm{Fe}^{0}$ filters will efficiently treat harvested and eventually blended rainwater. The initial concept [5] has been constantly actualized [42,113-118]. Moreover, it is in the framework of applying this concept for water defluoridation [42] that Heimann et al. [15] established the unsuitability of $\mathrm{Fe}^{0} / \mathrm{H}_{2} \mathrm{O}$ systems for quantitative fluoride removal $[14,19]$. The very last update of the concept is the one presented by Naseri et al. [85]. The authors have foreseen room for combining $\mathrm{Fe}^{0}$ filters with other technologies in multi-barrier systems, including those incorporating biochar.

\subsubsection{Biochar-Metal Iron Dual Water Filtration Systems}

The capacity of biochars and $\mathrm{Fe}^{0} / \mathrm{H}_{2} \mathrm{O}$ filters to remove microbiological and toxic chemicals is particularly important given their potential to pose human health risks. Moreover, as discussed in Section 5.1, in some instances, rainwater may contain pathogenic organisms and toxic metals such as $\mathrm{Pb}$ and $\mathrm{Zn}$ from roof materials. The application of a $\mathrm{Fe}^{0}$ filter in the final stage to polish water previously treated by biochar/biochar-sand filters is motivated by the fact that, $\mathrm{Fe}^{0}$ filters are efficient, but not sustainable due to rapid loss of porosity and hydraulic conductivity caused by the expansive nature of iron-corrosion products [4,118]. A water filter design based on this concept follows the pioneering 
vision proposed during the early development of $\mathrm{Fe}^{0}$ filtration systems $[5,85,119,120]$. In summary, the selection and complexity of the water filter design will strongly depend on the nature and severity of water contamination, and the local availability of materials for the fabrication of the filter. In this regard, one would expect that simple designs will be used for removal of single or a few contaminants, and while more complex designs are applied for the treatment of water with several contaminants.

Based on the criteria highlighted for appropriate water treatment methods, biochar water filters have several potential merits. For example, unlike other methods such as chlorination, biochar can be considered as renewable and cheap filter media that can be made from readily available biomaterials using local skills, hence ideal for low-income communities. Biochar also effectively remove physico-chemical and microbial contaminants even at low concentrations, unlike some existing methods (e.g., boiling, SODIS, and chlorination) that only remove microbial contaminants. Furthermore, biochar has minimal or no adverse effects on the treated water, and even maintains organoleptic properties of water. This is in contrast to other low-cost methods such as chlorination, which generates carcinogens, and boiling which potentially increases concentrations of dissolved inorganic contaminants such as $\mathrm{F}, \mathrm{U}$, and As.

Another unique feature of the biochar technology is its potential to generate other co-benefits besides the provision of clean drinking water. Biochar for treatment of drinking water can be produced by pyrolysis systems such as Kon tiki and biochar stoves during household heating and cooking. This is particularly important given that about $90 \%$ of the population in sub-Saharan Africa depends on biomass fuels for household heating and cooking. Compared to traditional open-fire cookstoves, biochar cookstoves are more efficient and burn cleanly, thereby releasing less toxic emissions and particulates. Coupling biochar production for water filters to household heating and cooking avoids the need to develop stand-alone systems solely for biochar production for water filters, which may increase labor demand, especially for women and children. In fact, it is postulated that this approach represents the potential logical entry point for biochar development and application in Africa [5]. Moreover, spent or excess biochar can be used as a soil conditioner to improve soil physico-chemical and biological properties, and hence crop yields. Soil application of biochar also sequesters soil carbon and reduces greenhouse gas emissions contributing to climate change and variability. Excess rainwater from the RWH, including that from potentially contaminated runoff catchments, may be used for irrigation of agro-ecosystems such as household nutrition and herbal gardens, which play a critical role in household food security and nutrition. In turn, the improved productivity of the agro-ecosystems will mean that more biomass feedstock in form of crop residues will be available for biochar production. Overall, integrating biochar and rainwater harvesting at a household or community level will transform the predominantly linear material flows (biomass, nutrients, water) into material cycles/loops consistent with the concept of sustainability.

\section{Water Analysis}

Information about water quality, including the fluoride content of natural waters, is essential to: (i) decide on the necessity of water treatment, (ii) select the treatment options, (iii) design the selected water treatment option(s) and control the quality of treated water. Analytical tools used to assess water quality are collectively based on well-known physico-chemical principles [121]. Such tools are used to ensure that drinking water meets international goals for safe drinking water $[3,42,122]$. These tools have been useful to characterize the extent of fluoride contamination in the EARV as well, and should support water supply efforts. However, the common perception is that the developing world lacks funds for instrumental analytical devices needed to characterize water quality. As an alternative, field-testing methods (test kits) and field-portable devices have been suggested [3]. However, they may be limited in availability, problematic in the implementation, and plagued with performance problems [122]. The whole reasoning is based on current international partnerships, in which Africa and the whole developing world is to receive new analytical tools from developed countries ultimately to help them address their needs. It is the conviction of the authors that affordable tools are already 
available and should be adapted and used. Ndé-Tchoupé et al. [42] regarded the equipment of accredited analytical water laboratories as the most important pre-requisite to assure universal safe drinking water supply. The idea is to mainly use colorimetric and potentiometric analytical methods, which are erroneously considered as 'outdated'. The rationale being that the methods are not outdated because of any inaccuracy, but because they are time-consuming. However, such methods are easier to operate and maintain, exactly the same way as the water treatment technologies used for low-income communities.

The use of test kits should be discouraged, not only because they are more expensive, but because kits are a mixture of chemicals that is mainly used in the field and would contribute to environmental pollution. On the contrary, wastes from an analytical laboratory should be locally treated or are treated in municipal plants. Tanzania already has experience with small analytical water laboratories. The Ngurdoto Defluoridation Research Station (NDRS—near Arusha) has been working on affordable defluoridation technologies for two decades. Table 1 presents an overview of water quality parameters and the corresponding analytical tools used at NDRS. The $\mathrm{pH}$ value and the electrical conductivity are measured in the field, while other chemical parameters are analyzed in the laboratory using standard methods. The equipment is excellently completed by a GPS giving the coordinates of sampling points.

A small water analytical laboratory can be equipped in each of the 44 districts within the six fluoride-affected regions and more modern laboratory equipped in the 2 or 3 cities (e.g., Arusha, Dar-es-Salem, and Dodoma). The existence of such facilities would serve to sustain, develop, and address prevailing challenges in analytical technology. This proposal is similar to what Mwamila [47] had in mind, when suggesting having water research centers as stand-alone entities for RWH sustainability and adoption. Locating these laboratories at the district level will provide room for working closely with the local communities, and explore available indigenous knowledge with potential for advancement.

Table 1. List of affordable water analytical methods used at NDRS (modified from Nkongo 2018-personal communication).

\begin{tabular}{ccc}
\hline Parameter & Units of Measurement & Methods \\
\hline $\mathrm{pH}$ & $\mathrm{pH} \mathrm{unit}$ & Potentiometric \\
Electrical conductivity & $\mathrm{\mu S} / \mathrm{cm}$ & Potentiometric \\
Total dissolved solids & $\mathrm{mg} / \mathrm{L}$ & Potentiometric \\
Total hardness & $\mathrm{mg} / \mathrm{L} \mathrm{CaCO}$ & EDTA titrimetric \\
Calcium & $\mathrm{mg} / \mathrm{L}$ & EDTA titrimetric \\
Magnesium & $\mathrm{mg} / \mathrm{L}$ & Calculation \\
Total alkalinity & $\mathrm{mg} / \mathrm{L} \mathrm{CaCO}$ & Titrimetric \\
Fluoride & $\mathrm{mg} / \mathrm{L}$ & Potentiometric (ISE) \\
Chloride & $\mathrm{mg} / \mathrm{L}$ & Argentometric \\
Carbonate & $\mathrm{mg} / \mathrm{L}$ & Titrimetric \\
Sulfate & $\mathrm{mg} / \mathrm{L}$ & Turbidimetric \\
Phosphate & $\mathrm{mg} / \mathrm{L}$ & Photometric \\
Iron & $\mathrm{mg} / \mathrm{L}$ & Photometric \\
Manganese & $\mathrm{mg} / \mathrm{L}$ & Photometric \\
Potassium & $\mathrm{mg} / \mathrm{L}$ & Potentiometric (ISE) \\
Sodium & $\mathrm{mg} / \mathrm{L}$ & Potentiometric (ISE) \\
\hline
\end{tabular}

\section{Mineralization of Treated Water}

The view that drinking water must contain a certain amount of some minerals (e.g., $\mathrm{Ca}^{2+}, \mathrm{Mg}^{2+}$, $\left.\mathrm{HCO}_{3}{ }^{-}\right)$is widespread and is the rationale for commercialized bottle waters [123,124]. Actually, harvested rainwater is practically mineral free and exhibits a $\mathrm{pH}$ value closer to 5.0 [12,13]. In nature, rainwater leaches minerals during its infiltration and its $\mathrm{pH}$ value increases [12,13]. The good point is that calcite $\left(\mathrm{CaCO}_{3}\right)$ dissolution in water (Equation (4)) is regulated by the $\mathrm{pH}$ and its equilibrium with 
the carbon dioxide [13]. For example, at relatively low $\mathrm{pH}$ values $\left(2 \mathrm{H}^{+}\right)$, calcite $\left(\mathrm{CaCO}_{3}\right)$ dissolution follows Equation (4), while at higher $\mathrm{pH}$ values $\left(\mathrm{H}^{+}\right)$, Equation (5) has an overriding effect.

$$
\begin{gathered}
\mathrm{CaCO}_{3}(\mathrm{~s})+2 \mathrm{H}^{+} \Leftrightarrow \mathrm{Ca}^{2+}+\mathrm{CO}_{2}+\mathrm{H}_{2} \mathrm{O} \\
\mathrm{CaCO}_{3}(\mathrm{~s})+\mathrm{H}^{+} \Leftrightarrow \mathrm{Ca}^{2+}+\mathrm{HCO}_{3}{ }^{-}
\end{gathered}
$$

Equations (4) and (5) suggest that well-designed columns filled with $\mathrm{CaCO}_{3}$ or $\mathrm{CaMg}\left(\mathrm{CO}_{3}\right)_{2}$ (dolomite) of a mixture thereof can fix the $\mathrm{pH}$ value of the harvested rainwater to values up to $\mathrm{pH} 8.5$ (where $\mathrm{CaCO}_{3}$ dissolution stops), which correspond to the $\mathrm{WHO}$ recommendations $(6.5 \leq \mathrm{pH} \leq 8.5)$. The extent of water mineralization and the final $\mathrm{pH}$ value depend mainly on: (i) the intrinsic reactivity of used minerals, (ii) the water flow velocity (residence time), and (iii) the initial $\mathrm{pH}$ value of the rainwater. It is expected that using mineral dissolution will locally produce various water qualities and trademarks. For example, a hypothetical brand name is, 'dolomite water from Tenguru'. This hypothetical brand uses dolomite from Tenguru to mineralize harvested and treated rainwater before it is distributed to the population. If dolomite from Tenguru produces a particular water, it creates a market for dolomite from this village, hosting the Campus of the Nelson Mandela Institution for Science and Technology (Arusha). Such an approach could potentially create possible value chains and employment in the rainwater harvesting sector.

\section{Concluding Remarks and Outlook}

Rainwater harvesting is mainly perceived as a low-technology water supply system for some regions lacking the following: (i) alternative pristine sources, and (ii) affordable, efficient water treatment technologies. In other cases, RWH eliminates the need to find or develop new water supply systems at small scale. The Kilimanjaro concept is innovative and combines: (i) using harvested rainwater, and (ii) seeking new pristine sources from far away to eliminate the challenging need to remove fluoride from natural water. A network for water collection and storage enables meeting local water demands and distant communities in need within the whole East African Rift Valley. In the Federal Republic of Tanzania, existing RWH promotion strategies should include: (i) investment in raising the awareness of citizens as well as capacity building; (ii) the provision of incentives and subsidies; (iii) the establishment of supportive legislation, and institutional and policy frameworks to promote the adoption of RWH; and (iv) investment in research on water resources as well as the establishment of research centers. This is essential to sustain RWH technology through addressing prevailing and upcoming challenges. Information and tools for promoting water conservation should be adapted to implement the Kilimanjaro concept.

However, the concept paper highlighted the potential of integrating RWH and low-cost water treatment systems to overcome fluorosis in Tanzania, but did not address detailed design and cost estimation of the proposed system. Therefore, the following aspects will need to be addressed in the detailed design process: (i) including institutional roles, and community contributions and participation, (ii) optimal location and sizing of conveyance and storage facilities to avoid excessive pumping costs, and (iii) project funding mechanisms, including any prospects for government subsidy. Moreover, some communities are likely to be self-reliant in drinking water and may export or 'sell' excess rainwater to communities in need. The details of the water transfer mechanism among self-reliant communities and those in need will need to be determined during the detailed design phase. The current paper provides the underpinning concept that will guide policy makers, researchers and other development partners on the long journey towards overcoming fluorosis through clean water provision.

Translating the concept into reality requires a supportive policy and institutional framework, and a shift from the misconception that technologies to solve problems in Africa are to be imported from the West (and the Orient). Rather than endlessly trying to find new low-cost technologies for water defluoridation, as Gleick [125] rightly stated, "it is time to plan for meeting present and future 
human needs with the water that is available". The Kilimanjaro concept also seeks to contribute other potential benefits, including preventing erosion and reducing flood risks, and their socio-economic impacts. Clearly, it is no more about discussing which big project should be next realized in the framework of meeting the UN SDGs, but to realize a thousand-permanent-job-project that will ensure self-reliance in water supply not only for the EARV. It is expected that the realization of the Kilimanjaro concept will consider local cultural values and recreational aspects as well. Finally, the article makes a bold statement that enough engineers and scientists exist in EARV region to start the ambitious work to develop the concept into a reality for the benefit of public health, while simultaneously empowering and increasing the self-confidence of African scientists and engineers to face other developmental challenges pervasive in Africa.

Author Contributions: M.L., Z.P.A., I.L., R.I.M., M.N., A.I.N.-T., J.M., W.G., T.B.M., M.A.R., R.T.-T., C.N., and K.N.N. contributed equally to manuscript compilation and revisions.

Funding: Ndé-Tchoupé A.I.'s research visit to Göttingen was supported by DAAD grant 91649464.

Acknowledgments: We acknowledge support by the German Research Foundation and the Open Access Publication Funds of the Göttingen University.

Conflicts of Interest: The authors declare no conflict of interest.

\section{References}

1. Sachs, J.D. Achieving the Sustainable Development Goals. J. Int. Bus. Ethics 2015, 8, 53-62.

2. Gleick, P. The human right to water. Water Policy 1999, 1, 487-503. [CrossRef]

3. Shannon, M.A.; Bohn, P.W.; Elimelech, M.; Georgiadis, J.G.; Marinas, B.J.; Mayes, A.M. Science and technology for water purification in the coming decades. Nature 2008, 452, 301-310. [CrossRef] [PubMed]

4. Hussam, A. Contending with a development disaster: SONO Filters remove arsenic from well water in Bangladesh. Innovations 2009, 4, 89-102. [CrossRef]

5. Noubactep, C.; Schöner, A.; Woafo, P. Metallic iron filters for universal access to safe drinking water. Clean-Soil Air Water 2009, 37, 930-937. [CrossRef]

6. Gwenzi, W.; Chaukura, N.; Noubactep, C.; Mukome, F.N.D. Biochar-based water treatment systems as a potential low-cost and sustainable technology for clean water provision. J. Environ. Manag. 2017, 197, 732-749. [CrossRef] [PubMed]

7. Hossain, M.A.; Mukharjee, A.; Sengupta, M.K.; Ahamed, S.; Das, B.; Nayak, B.; Pal, A.; Rahman, M.M.; Chakraborti, D. Million dollar arsenic removal plants in West Bengal, India: Useful or not? Water Qual. Res. J. Can. 2006, 41, 216-225. [CrossRef]

8. Indermitte, E.; Saava, A.; Karro, E. Reducing exposure to high fluoride drinking water in Estonia-A countrywide study. Int. J. Environ. Res. Public Health 2014, 11, 3132-3142. [CrossRef] [PubMed]

9. Wagutu, A.W.; Machunda, R.; Jande, Y.A.C. Crustacean derived calcium phosphate systems: Application in defluoridation of drinking water in East African rift valley. J. Hazard. Mater. 2018, 347, 95-105. [CrossRef]

10. Winde, F.; van der Walt, I.J. The significance of groundwater-stream interactions and fluctuating stream chemistry on waterborne uranium contamination of streams-A case study from a gold mining site in South Africa. J. Hydrol. 2004, 287, 178-196. [CrossRef]

11. Kalin, M.; Wheeler, W.N.; Meinrath, G. The removal of uranium from mining waste water using algal/microbial biomass. J. Environ. Radioact. 2005, 78, 151-177. [CrossRef] [PubMed]

12. Langmuir, D. Aqueous Environmental Geochemistry; Prentice Hall: Upper Saddle River, NJ, USA, 1997; 600p.

13. Appelo, C.A.J.; Postma, D. Geochemistry, Groundwater and Pollution, 2nd ed.; A.A. Balkema: Rotterdam, The Netherland, 2005; 536p.

14. Heimann, S. Testing granular iron for fluoride removal. Freiberg Online Geosci. 2018, 52, 1-80.

15. Heimann, S.; Ndé-Tchoupé, A.I.; Hu, R.; Licha, T.; Noubactep, C. Investigating the suitability of $\mathrm{Fe}^{0}$ packed-beds for water defluoridation. Chemosphere 2018, 209, 578-587. [CrossRef] [PubMed]

16. Oladoja, N.A.; Bello, G.A.; Obisesan, S.V.; Helmreich, B.; Ogunniyi, J.A.; Daramola, O.A.; Bello, H.A.; Anthony, E.T.; Saliu, T.D. Insight into the defluoridation efficiency of lateritic soil. Environ. Progr. Sust. Energy 2018. [CrossRef] 
17. Ndé-Tchoupé, A.I.; Nanseu-Njiki, C.P.; Hu, R.; Nassi, A.; Noubactep, C.; Licha, T. Characterizing the reactivity of metallic iron for water defluoridation in batch studies. Chemosphere 2019, 219, 855-863. [CrossRef] [PubMed]

18. Boruff, C.S. Removal of fluoride from drinking waters. Ind. Eng. Chem. 1936, 26, 69-71. [CrossRef]

19. Maier, F.J. Methods of removing fluorides from water. Am. J. Public Health 1947, 37, 1559-1566. [CrossRef]

20. Zevenbergen, C.; Van Reeuwijk, L.P.; Frapporti, G.; Louws, R.J.; Schuiling, R.D. A simple method for defluoridation of drinking water at village level by adsorption on Ando soil in Kenya. Sci. Total Environ. 1996, 188, 225-232. [CrossRef]

21. Mjengera, H.; Mkongo, G. Appropriate defluoridation technology for use in flourotic areas in Tanzania. Phys. Chem. Earth Parts A/B/C 2003, 28, 1097-1104. [CrossRef]

22. Bhatnagar, A.; Kumar, E.; Sillanpää, M. Fluoride removal from water by adsorption: A review. Chem. Eng. J. 2011, 171, 811-840. [CrossRef]

23. Carstairs, C. Debating water fluoridation before Dr. Strangelove. Am. J. Public Health 2015, 105, 1559-1569. [CrossRef] [PubMed]

24. Dahi, E. Africa's U-Turn in defluoridation policy: From the Nalgonda technique to bone char. Res. Rep. Fluoride 2016, 49 Pt 1, 401-416.

25. Marwa, J.; Lufingo, M.; Noubactep, C.; Machunda, R. Defeating fluorosis in the East African Rift Valley: Transforming the Kilimanjaro into a rainwater harvesting park. Sustainability 2018, 10, 4194. [CrossRef]

26. Ngigi, S.N. What is the limit of up-scaling rainwater harvesting in a river basin? Phys. Chem. Earth A B C 2003, 28, 943-956. [CrossRef]

27. Kahinda, J.M.; Lillie, E.S.B.; Taigbenu, A.E.; Taute, M.; Boroto, R.J. Developing suitability maps for rainwater harvesting in South Africa. Phys. Chem. Earth A B C 2008, 33, 788-799. [CrossRef]

28. Vohland, K.; Barry, B. A review of in situ rainwater harvesting (RWH) practices modifying landscape functions in African drylands. Agric. Ecosyst. Environ. 2009, 131, 119-127. [CrossRef]

29. Van Meter, K.J.; Basu, N.B.; Tate, E.; Wyckoff, J. Monsoon harvests: The living legacies of rainwater harvesting systems in South India. Environ. Sci. Technol. 2014, 48, 4217-4225. [CrossRef] [PubMed]

30. Nichols, W.R. Water Supply, Considered Mainly from a Chemical and Sanitary Standpoint; John Wiley \& Sons: New York, NY, USA, 1883; 260p.

31. Tucker, W.G. The purification of water by chemicaltreatment. Science 1892, 20, 34-38. [CrossRef]

32. Baker, M. Sketch of the history of water treatment. Am. Water Works Assoc. 1934, 26, 902-938. [CrossRef]

33. Howe, K.J.; Hand, D.W.; Crittenden, J.C.; Trussell, R.R.; Tchobanoglous, G. Principles of Water Treatment; John Wiley \& Sons, Inc.: Hoboken, NJ, USA, 2012; 674p.

34. Meinrath, G.; Merkel, B.; Ödegaard-Jensen, A.; Ekberg, C. Sorption of iron on surfaces: Modelling, data evaluation and measurement uncertainty. Acta hydrochim. Hydrobiol. 2004, 32, 154-160. [CrossRef]

35. Sperlich, A.; Werner, A.; Genz, A.; Amy, G.; Worch, E.; Jekel, M. Breakthrough behavior of granular ferric hydroxide (GFH) fixed-bed adsorption filters: Modeling and experimental approaches. Water Res. 2005, 39, 1190-1198. [CrossRef]

36. Worch, E. Adsorption Technology in Water Treatment; Walter de Gruyter GmbH \& Co., KG: Berlin, Germany; Boston, MA, USA, 2012; 345p.

37. Moraci, N.; Lelo, D.; Bilardi, S.; Calabrò, P.S. Modeling long-term hydraulic conductivity behaviour of zero valent iron column tests for permeable reactive barrier design. Can. Geotech. J. 2016, 53, 946-961. [CrossRef]

38. Noubactep, C. Predicting the hydraulic conductivity of metallic iron filters: Modeling gone astray. Water 2016, 8, 162. [CrossRef]

39. Brimicombe, A. GIS, Environmental Modeling and Engineering, 2nd ed.; CRC Press: Boca Raton, FL, USA, 2009; 378p.

40. Holzbecher, E. Environmental Modeling: Using MATLAB; Springer: Berlin, Germany, 2012.

41. World Bank. Reaching for the SDGs: The Untapped Potentialof Tanzania's Water Supply, Sanitation, and Hygiene Sector. WASH Poverty Diagnostic; World Bank: Washington, DC, USA, 2018; Available online: www.worldbank.org (accessed on 4 December 2018).

42. Ndé-Tchoupé, A.I.; Crane, R.A.; Mwakabona, H.T.; Noubactep, C.; Njau, K.N. Technologies for decentralized fluoride removal: Testing metallic iron-based filters. Water 2015, 7, 6750-6774. [CrossRef]

43. Pittalis, D. Interdisciplinary Studies for the Knowledge of the Groundwater Fluoride Contamination in the Eastern African Rift: Meru District-North Tanzania. Ph.D. Thesis, University of Sassari, Sassari, Italy, 2010. 
44. Bhattacharya, P.; Lesafi, F.; Filemon, R.; Ligate, F.; Ijumulana, J.; Mtalo, F. Geogenic fluoride and arsenic contamination in the groundwater environments in Tanzania. In Proceedings of the EGU General Assembly Conference Abstracts, Vienna, Austria, 17-22 April 2016; Volume 18, p. 16677.

45. Malago, J.; Makoba, E.; Muzuka, A.N.N. Fluoride levels in surface and groundwater in Africa: A review. Am. J. Water Sci. Eng. 2017, 3, 1-17. [CrossRef]

46. Mbilinyi, B.P.; Tumbo, S.D.; Mahoo, H.F.; Senkondo, E.M.; Hatibu, N. Indigenous knowledge as decision support tool in rainwater harvesting. Phys. Chem. Earth 2005, 30, 792-798. [CrossRef]

47. Mwamila, T.B. Rainwater Harvesting Potential and Management Strategies for Sustainable Water Supply in Tanzania. Ph.D. Thesis, Seoul National University, Seoul, Korea, 2016.

48. Mwamila, T.; Han, M.; Ndomba, P. Performance evaluation of rainwater harvesting system and strategy for dry season challenge. J. Water Pract. Technol. 2016, 11, 829-837. [CrossRef]

49. Mwamila, T.B.; Han, M.Y.; Kum, S. Sustainability evaluation of a primary school rainwater demonstration project in Tanzania. J. Water Sanit. Hygiene 2016. [CrossRef]

50. Mwamila, T.B.; Katambara, Z.; Han, M.Y. Strategies for household water supply improvement with rainwater harvesting. J. Geosci. Environ. Prot. 2016, 4, 146-158. [CrossRef]

51. Mwamila, T.B.; Mooyoung, H.; Katambara, Z. Strategy to Overcome Barriers of Rainwater Harvesting, Case Study Tanzania. Geosci. Environ. Prot. 2016, 4, 13-23. [CrossRef]

52. U.S. Environmental Protection Agency (USEPA). How Wastewater Treatment Works ... The Basics; EPA-833-F 98002; U.S. Environmental Protection Agency: Cincinnati, OH, USA, 1984.

53. Moglia, M.; Gana, K.; Delbridge, N. Exploring methods to minimize the risk of mosquitoes in rainwater harvesting systems. J. Hydrol. 2016, 543, 324-329. [CrossRef]

54. Su, M.D.; Lin, C.H.; Chang, L.F.; Kang, J.L.; Lin, M.C. A probabilistic approach to rainwater harvesting systems design and evaluation. Resour. Conserv. Recycl. 2009, 53, 393-399. [CrossRef]

55. Imteaz, M.A.; Ahsan, A.; Shanableh, A. Reliability analysis of rainwater tanks using daily water balance model: Variations within a large city. Resour. Conserv. Recycl. 2013, 77, 37-43. [CrossRef]

56. Rahman, M.A.; Wiegand, B.A.; Badruzzaman, A.B.M.; Ptak, T. Hydrogeological analysis of the upper Dupi Tila Aquifer, towards the implementation of a managed aquifer-recharge project in Dhaka City, Bangladesh. Hydrogeol. J. 2013, 21, 1071-1089. [CrossRef]

57. Gwenzi, W.; Nyamadzawo, G. Hydrological impacts of urbanization and urban roof water harvesting in water-limited catchments: A review. Environ. Process. 2014, 1, 573-593. [CrossRef]

58. MWLD. National Water Policy; Ministry of Water and Livestock Development: Dar es Salaam, Tanzania, 2002.

59. MoWI. National Water Sector Development Strategy-2006 to 2015; Ministry of Water and Irrigation: Dar es Salaam, Tanzania, 2008.

60. Water Resources Management Act. Act Supplement No. 11, Gazette of the United Republic of Tanzania No. 20 Volume 90, Dated 15 May 2009; Government Printer: Dar es Salaam, Tanzania, 2009.

61. NBS. Basic Facts and Figures on Human Settlements 2012, Tanzania Mainland; National Bureau of Statistics, Ministry of Finance: Dar es Salaam, Tanzania, 2013.

62. Malesu, M.; Khaka, E.; Mati, B.; Oduor, A.; Bock, T.D.; Nyabenge, M.; Oduor, V. Mapping the Potentials for Rainwater Harvesting Technologies in Africa: A Gis Overview on Development Domains for The Continent and Nine Selected Countries; Technical Manual No. 7; World Agroforestry Centre (ICRAF), Netherlands Ministry of Foreign Affairs: Nairobi, Kenya, 2006.

63. Thomas, T.H.; Martinson, D.B. Roofwater Harvesting: A Handbook for Practitioners; IRC International Water and Sanitation Centre: Delft, The Netherlands, 2007.

64. Mendez, C.; Klenzendorf, J.B.; Afshar, B.R.; Simmons, M.T.; Barret, M.E.; Kinney, K.A.; Kirisits, M.J. The effect of roofing material on the quality of harvested rainwater. Water Res. 2011, 45, 2049-2059. [CrossRef]

65. Lee, J.Y.; Bak, G.; Han, M.Y. Quality of roof-harvested rainwater-Comparison of different roofing materials. Environ. Pollut. 2012, 162, 422-429. [CrossRef]

66. Amin, M.T.; Kim, T.I.; Amin, M.N.; Han, M.Y. Effects of catchment, first flush, storage conditions, and time on microbial quality in rainwater harvesting systems. Water Environ. Res. 2013, 85, 2317-2329. [CrossRef]

67. Heyworth, J.S.; Glonek, G.; Maynard, E.J.; Baghurt, P.A.; Finlay-Jones, J. Consumption of untreated tank rainwater and gastroenteritis among young children in South Australia. Int. J. Epidemiol. 2006, 35, 1051-1058. [CrossRef] 
68. Rodrigo, S.; Sinclair, M.; Cunliffe, D.; Leder, K. A Critical Assessment of Epidemiological Studies for the Investigation of the Health Risk of Drinking Untreated Rainwater. In Rainwater and Urban Design 2007; Engineers Australia: Barton, Australia, 2007; pp. 936-943. Available online: https:/ / search.informit.com.au/ documentSummary; dn=889900316059723;res=IELENG (accessed on 28 November 2018).

69. Ahmed, W.; Brandes, H.; Gyawali, P.; Sidhu, J.P.; Toze, S. Opportunistic pathogens in roof-captured rainwater samples, determined using quantitative PCR. Water Res. 2014, 15, 361-369. [CrossRef]

70. Zhang, Q.; Wang, X.; Hou, P.; Wan, P.; Ouyang, Z. Quality and seasonal variation of rainwater harvested from concrete, asphalt, ceramic tile and green roofs in Chongqing, China. J. Environ. Manag. 2014, 132, 178-187. [CrossRef] [PubMed]

71. Dobrowsky, P.H.; De Kwaadsteniet, M.; Cloete, T.E.; Khan, W. Distribution of indigenous bacterial pathogens and potential pathogens associated with roof-harvested rainwater. Appl. Environ. Microbiol. 2014, 80, 2307-2316. [CrossRef] [PubMed]

72. Dobrowsky, P.H.; van Deventer, A.; De Kwaadsteniet, M.; Ndlovu, T.; Khan, S.; Cloete, T.E.; Khan, W. Prevalence of virulence genes associated with pathogenic Escherichia coli strains isolated from domestically harvested rainwater during low- and high-rainfall periods. Appl. Environ. Microbiol. 2014, 80, 1633-1638. [CrossRef] [PubMed]

73. Jesmi, Y.; Rahiman, K.M.; Hatha, A.A.; Deepu, L.; Jyothi, S. Risk assessment of rooftop-collected rainwater for individual household and community use in central Kerala, India. J. Environ. Health. 2014, 76, 114-121. [PubMed]

74. Lye, D. Rooftop Runoff as a Source of Contamination: A Review. USEPA. 2014 Rainwater Resources. Available online: http:/ / www.rainwaterresources.com/rooftoprunoff-source-contaminationreview (accessed on 6 October 2014).

75. Gwenzi, W.; Dunjana, N.; Pisa, C.; Tauro, T.; Nyamadzawo, G. Water quality and public health risks associated with roof rainwater harvesting systems for potable supply: Review and perspectives. Sustain. Water Qual. Ecol. 2015, 6, 107-118. [CrossRef]

76. Chang, M.; McBroom, M.W.; Beasley, R.S. Roofing as a source of nonpoint water pollution. J. Environ. Manag. 2004, 73, 307-315. [CrossRef] [PubMed]

77. Adeniyi, I.F.; Olabanji, I.O. The physico-chemical and bacteriological quality of rainwater collected over different roofing materials in Ile-Ife, southwestern Nigeria. Chem. Ecol. 2005, 21, 149-166. [CrossRef]

78. Ahmed, W.; Vieritz, A.; Goonetilleke, A.; Gardner, T. Health risk from the use of roof-harvested rainwater as potable or non-potable water, determined using quantitative microbial risk assessment in Southeast Queensland, Australia. Appl. Environ. Microbiol. 2010, 76, 7382-7391. [CrossRef]

79. Ahmed, W.; Gardner, T.; Toze, S. Microbiological quality of roof-harvested rainwater and health risks: A review. J. Environ. Qual. 2011, 40, 13-21. [CrossRef]

80. Ahmed, W.; Sidhu, J.P.; Toze, S. Speciation and frequency of virulence genes of Enterococcus spp. isolated from rainwater tank samples in Southeast Queensland, Australia. Environ. Sci. Technol. 2012, 46, 6843-6850. [CrossRef]

81. Lauderdale, R.A.; Emmons, A.H. A method for decontaminating small volumes of radioactive water. J. Am. Water Works Assoc. 1951, 43, 327-331. [CrossRef]

82. Banerji, T.; Chaudhari, S. A cost-effective technology for arsenic removal: Case study of zerovalent iron-based IIT Bombay arsenic filter in West Bengal. In Water and Sanitation in the New Millennium; Nath, K., Sharma, V., Eds.; Springer: New Delhi, India, 2017. [CrossRef]

83. Mwakabona, H.T.; Ndé-Tchoupé, A.I.; Njau, K.N.; Noubactep, C.; Wydra, K.D. Metallic iron for safe drinking water provision: Considering a lost knowledge. Water Res. 2017, 117, 127-142. [CrossRef] [PubMed]

84. Makota, S.; Nde-Tchoupe, A.I.; Mwakabona, H.T.; Tepong-Tsindé, R.; Noubactep, C.; Nassi, A.; Njau, K.N. Metallic iron for water treatment: Leaving the valley of confusion. Appl. Water Sci. 2017. [CrossRef]

85. Naseri, E.; Ndé-Tchoupé, A.I.; Mwakabona, H.T.; Nanseu-Njiki, C.P.; Noubactep, C.; Njau, K.N.; Wydra, K.D. Making $\mathrm{Fe}^{0}$-based filters a universal solution for safe drinking water provision. Sustainability 2017, 9, 1224. [CrossRef]

86. Hu, R.; Cui, X.; Gwenzi, W.; Wu, S.; Noubactep, C. $\mathrm{Fe}^{0} / \mathrm{H}_{2} \mathrm{O}$ systems for environmental remediation: The scientific history and future research directions. Water 2018, 10, 1739. [CrossRef]

87. Hu, R.; Noubactep, C. Iron corrosion: Scientific heritage in jeopardy. Sustainability 2018, 10, 4138. [CrossRef] 
88. Gwenzi, W.; Chaukura, N.; Mukome, F.; Machado, S.; Nyamasoka, B. Biochar production and applications in sub-Saharan Africa: Opportunities, constraints, risks and uncertainties. J. Environ. Manag. 2016, 150, 250-261. [CrossRef]

89. Gwenzi, W. Biochar cookstoves as a potential clean energy source for household heating and cooking in developing countries. In Non-Soil Biochar Applications; Kalderis, D., Ntarlagiannis, D., Soupios, P., Eds.; Nova Science Publishers: New York, NY, USA, 2018.

90. Mohan, D.; Sarswat, A.; Ok, Y.S.; Pittman, C.U., Jr. Organic and inorganic contaminants removal from water with biochar, a renewable, low cost and sustainable adsorbent-A critical review. Bioresour. Technol. 2014, 160, 191-202. [CrossRef]

91. Devonshire, E. The purification of water by means of metallic iron. J. Frankl. Inst. 1890, 129, 449-461. [CrossRef]

92. Van Craenenbroeck, W. Easton \& Anderson and the water supply of Antwerp (Belgium). Ind. Archaeol. Rev. 1998, 20, 105-116.

93. James, B.R.; Rabenhorst, M.C.; Frigon, G.A. Phosphorus sorption by peat and sand amended with iron oxides or steel wool. Water Environ. Res. 1992, 64, 699-705. [CrossRef]

94. Harza Environmental Services. Fundamental Aspects of Selenium Removal by Harza Process; Technical Report Prepared under Contract for the Federal-State San Joaquin Valley Drainage Program; Sacramento, CA, USA, 1989.

95. Khan, A.H.; Rasul, S.B.; Munir, A.K.M.; Habibuddowla, M.; Alauddin, M.; Newaz, S.S.; Hussam, A. Appraisal of a simple arsenic removal method for groundwater of bangladesh. J. Environ. Sci. Health A 2000, 35, 1021-1041. [CrossRef]

96. Erickson, A.J.; Gulliver, J.S.; Weiss, P.T. Enhanced sand filtration for storm water phosphorus removal. J. Environ. Eng. 2007, 133, 485-497. [CrossRef]

97. Hussam, A.; Munir, A.K.M. A simple and effective arsenic filter based on composite iron matrix: Development and deployment studies for groundwater of Bangladesh. J. Environ. Sci. Health A 2007, 42, 1869-1878. [CrossRef] [PubMed]

98. You, Y.; Han, J.; Chiu, P.C.; Jin, Y. Removal and inactivation of waterborne viruses using zerovalent iron. Environ. Sci. Technol. 2005, 39, 9263-9269. [CrossRef] [PubMed]

99. Tellen, V.; Nkeng, G.; Dentel, S. Improved filtration technology for pathogen reduction in rural water supplies. Water 2010, 2, 285-306. [CrossRef]

100. Ingram, D.T.; Callahan, M.T.; Ferguson, S.; Hoover, D.G.; Chiu, P.C.; Shelton, D.R.; Millner, P.D.; Camp, M.J.; Patel, J.R.; Kniel, K.E.; et al. Use of zero-valent iron biosand filters to reduce Escherichia coli O157:H12 in irrigation water applied to spinach plants in a field setting. J. Appl. Microbiol. 2012, 112, 551-560. [CrossRef]

101. Shi, Z.; Fan, D.; Johnson, R.L.; Tratnyek, P.G.; Nurmi, J.T.; Wu, Y.; Williams, K.H. Methods for characterizing the fate and effects of nano zerovalent iron during groundwater remediation. J. Contam. Hydrol. 2015, 181, 17-35. [CrossRef]

102. Lefevre, E.; Bossa, N.; Wiesner, M.R.; Gunsch, C.K. A review of the environmental implications of in situ remediation by nanoscale zero valent iron (nZVI): Behavior, transport and impacts on microbial communities. Sci. Tot. Environ. 2016, 565, 889-901. [CrossRef]

103. Noubactep, C. On the mechanism microbe inactivation by metallic iron. J. Hazard. Mater. 2011, 198, $383-386$. [CrossRef]

104. Cantrell, K.J.; Kaplan, D.I.; Wietsma, T.W. Zero-valent iron for the in situ remediation of selected metals in groundwater. J. Hazard. Mater. 1995, 42, 201-212. [CrossRef]

105. Ponder, S.; Darab, J.; Mallouk, T. Remediation of $\mathrm{Cr}(\mathrm{VI})$ and $\mathrm{Pb}(\mathrm{II})$ aqueous solutions using supported, nanoscale zero-valent iron. Environ. Sci. Technol. 2000, 34, 2564-2569. [CrossRef]

106. Morrison, S.J.; Metzler, D.R.; Dwyer, B.P. Removal of As, Mn, Mo, Se, U, V and Zn from groundwater by zero-valent iron in a passive treatment cell: Reaction progress modeling. J. Contam. Hydrol. 2002, 56, 99-116. [CrossRef]

107. Wilkin, R.T.; Mcneil, M.S. Laboratory evaluation of zero-valent iron to treat water impacted by acid mine drainage. Chemosphere 2003, 53, 715-725. [CrossRef]

108. Bartzas, G.; Komnitsas, K.; Paspaliaris, I. Laboratory evaluation of $\mathrm{Fe}^{0}$ barriers to treat acidic leachates. Miner. Eng. 2006, 19, 505-514. [CrossRef] 
109. Rangsivek, R.; Jekel, M.R. Removal of dissolved metals by zero-valent iron (ZVI): Kinetics, equilibria, processes and implications for stormwater runoff treatment. Water Res. 2005, 39, 4153-4163. [CrossRef] [PubMed]

110. Zhang, X.; Lin, S.; Lu, X.Q.; Chen, Z.L. Removal of Pb(II) from water using natural kaolin loaded with synthesized nanoscale zero-valent iron. Chem. Eng. J. 2010, 163, 243-248. [CrossRef]

111. Kishimoto, N.; Iwano, S.; Narazaki, Y. Mechanistic consideration of zinc removal by zero-valent iron. Water Air Soil Pollut. 2011, 221, 183-189. [CrossRef]

112. Kim, S.A.; Kamala-Kannan, S.; Lee, K.-J.; Park, Y.-J.; Shea, P.J.; Lee, W.- H.; Kim, H.-M.; Oh, B.-T. Removal of $\mathrm{Pb}$ (II) from aqueous solution by a zeolite-nanoscale zero-valent iron composite. Chem. Eng. J. 2013, 217, 54-60. [CrossRef]

113. Noubactep, C.; Schöner, A. Metallic iron: Dawn of a new era of drinking water treatment research? Fresenius Environ. Bull. 2010, 19, 1661-1668.

114. Caré, S.; Crane, R.; Calabrò, P.S.; Ghauch, A.; Temgoua, E.; Noubactep, C. Modeling the permeability loss of metallic iron water filtration systems. CLEAN Soil Air Water 2013, 41, 275-282. [CrossRef]

115. Domga, R.; Togue-Kamga, F.; Noubactep, C.; Tchatchueng, J.B. Discussing porosity loss of Fe ${ }^{0}$ packed water filters at ground level. Chem. Eng. J. 2015, 263, 127-134. [CrossRef]

116. Noubactep, C.; Temgoua, E.; Rahman, M.A. Designing iron-amended biosand filters for decentralized safe drinking water provision. CLEAN Soil Air Water 2012, 40, 798-807. [CrossRef]

117. Tepong-Tsindé, R.; Crane, R.; Noubactep, C.; Nassi, A.; Ruppert, H. Testing metallic iron filtration systems for decentralized water treatment at pilot scale. Water 2015, 7, 868-897. [CrossRef]

118. Rahman, M.A.; Karmakar, S.; Salama, H.; Gactha-Bandjun, N.; Btatkeu-K, B.D.; Noubactep, C. Optimising the design of $\mathrm{Fe}^{0}$-based filtration systems for water treatment: The suitability of porous iron composites. J. Appl. Solut. Chem. Model. 2013, 2, 165-177.

119. Anderson, W. On the purification of water by agitation with iron and by sand filtration. J. Soc. Arts 1886, 35, 29-38. [CrossRef]

120. Anderson, M.A. Fundamental Aspects of Selenium Removal by Harza Process; Rep San Joaquin Valley Drainage Program; U.S. Department of the Interior: Sacramento, CA, USA, 1989.

121. Illman, D.L. Water analysis in the developing world. Anal. Chem. 2006, 78, 5266-5272. [CrossRef]

122. Lilje, J.; Mosler, H.-J. Continuation of health behaviors: Psychosocial factors sustaining drinking water chlorination in a longitudinal study from Chad. Sustainability 2016, 8, 1149. [CrossRef]

123. Grady, C.; Younos, T. Bottled water technology and its global ramifications: An overview. Int Water Technol. J. 2012, 2, 185-194.

124. Fugedi, U.; Kuti, L.; Jordan, G.; Kerek, B. Investigation of the hydrogeochemistry of some bottled mineral waters in Hungary. J. Geochem. Explor. 2010, 107, 305-316. [CrossRef]

125. Gleick, P.H. A look at twenty-first century water resources development. Water Inter. 2000, 25, 127-138. [CrossRef]

(C) 2019 by the authors. Licensee MDPI, Basel, Switzerland. This article is an open access article distributed under the terms and conditions of the Creative Commons Attribution (CC BY) license (http:// creativecommons.org/licenses/by/4.0/). 